\title{
A Holistic Approach to Upwelling and Downwelling along the South-West Coast of India
}

\author{
Phiros Shah $^{\mathrm{a}, \mathrm{b}}$, R. Sajeev ${ }^{\mathrm{a}}$, K. J. Thara ${ }^{\mathrm{a}}$, Grinson George ${ }^{\mathrm{b}}$, \\ Muhammad Shafeeque ${ }^{a, b}$, S. Akash ${ }^{b, c}$, and Trevor Platt ${ }^{b, d}$ \\ aDepartment of Physical Oceanography, School of Marine Sciences, Cochin University of Science \\ and Technology, Kochi, India; ${ }^{b}$ Fishery Resources Assessment Division, Central Marine Fisheries \\ Research Institute, Kochi, India; 'Academy of Climate Change Education and Research,

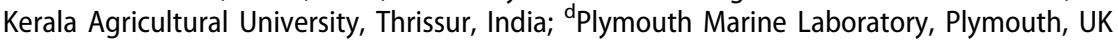

\begin{abstract}
An attempt has been made to develop a holistic understanding of upwelling and downwelling along the south-west coast of India. The main objective was to elucidate the roles of different forcings involved in the vertical motion along this coast. The south-west coast of India was characterized by upwelling during the south-west monsoon (May to September) and by downwelling during the north-east monsoon and winter (November to February). The average vertical velocity calculated along the south-west coast from the vertical shift of the $26^{\circ} \mathrm{C}$ isotherm is $0.57 \mathrm{~m} /$ day during upwelling and $0.698 \mathrm{~m} /$ day during downwelling. It was concluded that upwelling along the south-west coast of India is driven by offshore Ekman transport due to the alongshore wind, Ekman pumping, horizontal divergence of currents and by the propagation of coastally trapped waves. Whereas downwelling along the coast is driven only by convergence of currents and the propagation of coastally trapped Kelvin waves. Along the west coast of India, the downwelling-favorable Kelvin waves come from the equator and upwelling-favorable waves come from the Gulf of Mannar region.
\end{abstract}

\section{ARTICLE HISTORY}

Received 24 May 2017

Accepted 12 November 2018

\section{KEYWORDS}

Coastally trapped waves; downwelling; Ekman transport; Ekman pumping; equatorial Indian Ocean; south-west coast of India; upwelling

\section{Introduction}

Identifying the location of upwelling and downwelling zones in coastal waters is important because their vertical motions have significant influence on the environmental conditions in which the pelagic ecosystem is embedded. Vertical motions are a strong determinant of biological productivity in the sea. Since the west coast of India is the principal eastern boundary of the Arabian Sea, the upwelling and downwelling along the west coast of India determine the major part of biological production over the eastern Arabian Sea. Growth of fishes depends on food supply; 
therefore coastal upwelling and downwelling zones regulate annual fishery production (Thara 2011). This is the basis of the economic importance of upwelling and downwelling. From the previous literature it is evident that the west coast of India contributes $70 \%$ of total fishery production over the Arabian Sea (Luis and Kawamura 2004). The west coast of India is one of the most biologically productive regions of the world oceans, supporting considerable fishery resources by virtue of well-known upwelling processes during the summer monsoon season (Madhupratap et al. 1994, 1996, 2001). Against this background, the present study is focused on the upwelling and downwelling along west coast of India.

The upwelling and downwelling along the west coast of India are associated mainly with the west India coastal current system (WICC). Several authors in the past studied WICC as the major eastern boundary current in the north Indian Ocean. During the summer monsoon, the WICC flows towards the equator along the west coast of India and reverses its direction towards the pole during the winter monsoon (Clarke 1983; Potemra, Luther, and O'Brien 1991; Yu, O’Brien, and Yang 1991; McCreary, Kundu, and Molinari 1993; McCreary et al. 1996; Shetye and Gouveia 1998; Schott and McCreary 2001; Shankar, Vinayachandran, and Unnikrishnan 2002). The coast was characterized by upwelling during the summer monsoon and downwelling during the winter monsoon (Rao, Joshi, and Ravichandran 2008).

According to previous studies over the west coast of India; upwelling areas are characterized by upward motion of isotherms/isopycnals, cooling of sea surface temperature and fall in sea level (Sharma 1978; Gopalakrishna et al. 2008; Smitha et al. 2008; Jayaram et al. 2010: Shah, Sajeev, and Gopika 2015; Shah et al. 2018), whereas downwelling areas are characterized by downward motion of isotherms/isopycnals, and rise in sea surface temperature and sea level. Upwelling along the west coast of India starts during March-April in the southern latitudes and is intensified and propagates northward as the monsoon progresses (Banse 1959, 1968; Sharma 1978; Johannessen, Subbaraju, and Blindheim 1987). In the southern latitudes, upwelling ceases during October. Upwelling along the west coast of India is modulated by wind-induced Ekman dynamics (Shetye et al. 1985; Shetye and Shenoi 1988; Pankajakshan, Pattnaik, and Ghosh 1997) and coastally trapped wave propagation (Gopalakrishna et al. 2008; Rao et al. 2010) during the southwest monsoon. On the west coast of India, upwelling-favorable conditions exist along the southern shelf, with a decreasingly conspicuous surface manifestation towards the North (Muraleedharan and Prasanna Kumar 1996; Smitha et al. 2008). Both upwelling and downwelling along the west coast of India have an offshore extension of $350-400 \mathrm{~km}$ away from the coast (Antony, Narayana, and Somayajulu 2002) and the offshore extent of upwelling was reduced significantly from south to 
north (Sanilkumar, Unni, and James 2004). The offshore extent of upwelling/ downwelling is wider than the shelf over the southern latitudes, whereas it is limited to the shelf width over the northern latitudes. Compared to the south-west coast, north-west coast of India has a wider continental shelf (Carton, L'Hegaret, and Baraille 2012). A modeling study of Rao, Joshi, and Ravichandran (2008) concluded that upwelling along the southwest coast of India peaks during July and its intensity decreases towards North. Their study also revealed that temperature inversion along the coast is dependent mainly on downwelling during winter monsoon.

Analyzing the sinking process in the central Arabian Sea, Ramesh and Krishnan (2005) concluded that downward transfer of warm waters from the surface into the thermocline is dependent mainly on the combined effects of strong wind-driven mixing by the monsoonal winds and weak density stratification in the upper ocean. Their study also revealed that negative buoyancy flux also plays a major role in the convective deepening and cooling of the mixed layer.

The upwelling along the south-west coast of India has been addressed by several authors. Nevertheless until now the studies of the downwelling along this coast are relatively rare. Hence, the present study is an integrated attempt to study the upwelling and downwelling along the south-west coast of India from $8^{\circ} \mathrm{N}$ to $16^{\circ} \mathrm{N}$ with the aid of different in situ and satellite climatology.

The remaining part of the paper is organized as follows. Section 2 deals with the different data used and methodology adopted for the study. Section 3 presents results of various observations on upwelling and downwelling and a discussion on forcing mechanism involved in the vertical motion along the south-west coast of India. Section 4 concludes the paper.

\section{Data and methodology}

The grids selected for the study over the $200 \mathrm{~m}$ isobath lines along the south-west coast of India are shown in Figure 1. A climatology-based study is attempted here to understand the upwelling and downwelling along the south-west coast of India. Different oceanographic and meteorological data sets used in the present study are presented in Table 1. Since the upwelling and downwelling areas are characterized by the upward and downward movement of isotherms, the vertical distribution of temperature is used as a proxy for the identification of upwelling and downwelling zones. Depth of $26^{\circ} \mathrm{C}$ isotherms and vertical profile of the temperature are used to study the seasonal oscillation of the subsurface waters. Conventional explanation of coastal upwelling and downwelling favors offshore and onshore Ekman transport due to the alongshore winds. 


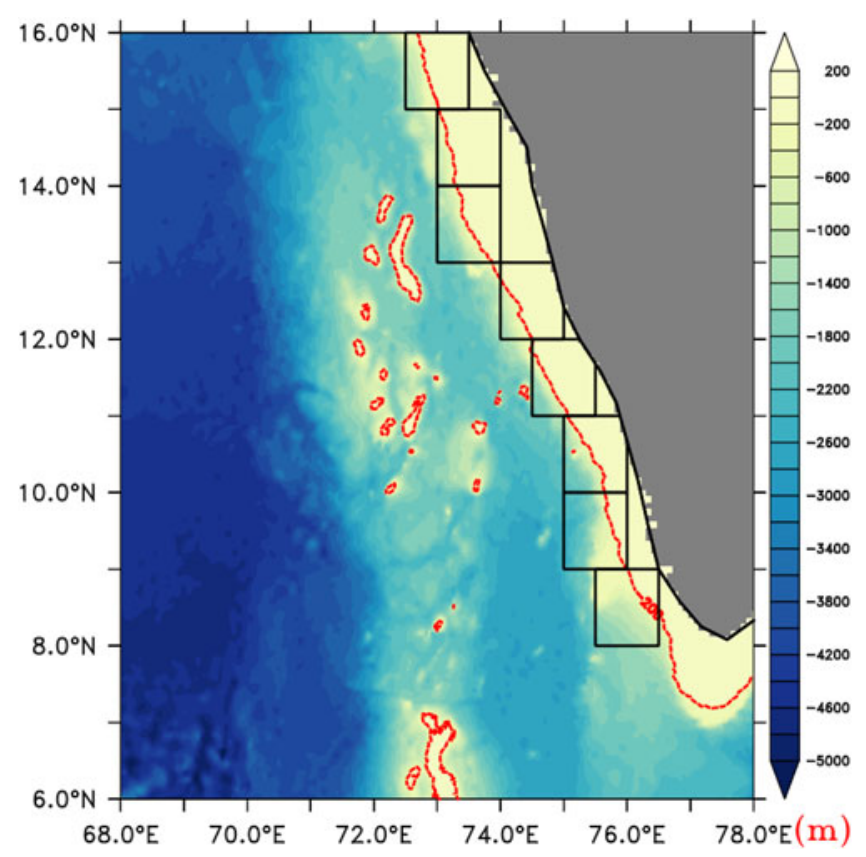

Figure 1. Location map and $1^{\circ} \times 1^{\circ}$ coastal boxes selected for the study. Red contour lines represents the $200 \mathrm{~m}$ isobath line. [Color scale represents the bathymetric depth in meter].

Table 1. Different oceanographic data used for the study.

\begin{tabular}{|c|c|c|c|c|c|}
\hline \multirow[b]{2}{*}{ Data } & \multicolumn{2}{|c|}{ Resolution } & \multirow[b]{2}{*}{ Source } & \multirow[b]{2}{*}{ Time span } & \multirow[b]{2}{*}{ Version } \\
\hline & Spatial & Temporal & & & \\
\hline $\begin{array}{l}\text { Zonal and } \\
\text { Meridional } \\
\text { current velocity }\end{array}$ & $0.25^{\circ} \times 0.25^{\circ}$ & Monthly & $\begin{array}{l}\text { Simple Ocean Data } \\
\text { Assimilation (SODA) }\end{array}$ & 1990-2010 & Version 3.3 .1 \\
\hline Temperature & $1^{\circ} \times 1^{\circ}$ & Monthly & $\begin{array}{l}\text { North Indian Ocean } \\
\text { Atlas (NIOA) }\end{array}$ & climatology & $\begin{array}{l}\text { Chatterjee } \\
\text { et al. (2012) }\end{array}$ \\
\hline $\begin{array}{l}\text { Zonal and } \\
\text { Meridional } \\
\text { wind velocity }\end{array}$ & $0.25^{\circ} \times 0.25^{\circ}$ & Monthly & $\begin{array}{l}\text { Quick } \\
\text { Scatterometer } \\
\text { (QuickSCAT) }\end{array}$ & 2000-2009 & - \\
\hline $\begin{array}{l}\text { Zonal and } \\
\text { Meridional } \\
\text { wind velocity }\end{array}$ & $1^{\circ} \times 1^{\circ}$ & Daily & $\begin{array}{l}\text { Advanced } \\
\text { Scatterometer } \\
\text { (ASCAT) }\end{array}$ & 2009-2016 & - \\
\hline Bathymetry & Modified etopo2 & - & $\begin{array}{l}\text { National Institute of } \\
\text { Oceanography, Goa }\end{array}$ & - & $\begin{array}{l}\text { Sindhu } \\
\text { et al. (2007) }\end{array}$ \\
\hline $\begin{array}{l}\text { Sea Level } \\
\quad \text { Anomaly (MDT) }\end{array}$ & $0.25^{\circ} \times 0.25^{\circ}$ & Daily & AVISO & 1993-2015 & L4 \\
\hline
\end{tabular}

Ekman pumping associated with the divergence and convergence of surface waters due to the wind stress curl also determine the strength of upwelling and downwelling (Vinayachandran et al. 2004).

Ekman transport along the west coast of India is calculated as follows:

$$
U_{e}=\tau_{y} / f
$$


and

$$
V_{e}=-\tau_{x} / f,
$$

where $U_{E}$ is mass transport by the alongshore wind; $V_{E}$ is the mass transport by the cross shore wind, $\tau_{y}$ is the alongshore wind stress; $\tau_{x}$ is the cross-shore wind stress; $f$ is the Coriolis parameter $(2 \Omega \sin \varphi) ; \Omega$ is the angular frequency of the Earth's rotation and $\varphi$ is the geographic latitude. Along the west coast of India, the alongshore and cross-shore components of wind speed were obtained with reference to the inclination of the coastline based on Shah, Sajeev, and Gopika (2015).

Ekman pumping velocity is calculated from the divergence of Ekman transport as follows:

$$
W_{E}=\frac{\partial U e}{\partial x}+\frac{\partial V e}{\partial x}
$$

To understand the strength and direction of the current induced by the wind, the study also analyses the depth mean Ekman drift along the southwest coast of India:

$$
U_{e d}=\frac{\tau}{\rho D f},
$$

where $U_{e d}$ is the depth mean Ekman drift and its direction is $90^{\circ}$ right to the wind direction. $\rho$ is the average density of sea water, $D$ is the Ekman depth and is derived from vertical eddy diffusivity and Coriolis parameter

$$
D=\frac{\sqrt{ } 2 A}{\sqrt{f}},
$$

where $A$ is the vertical eddy diffusivity whose value is fixed at $10^{-2} \mathrm{~m}^{2} / \mathrm{s}$ for the north Indian Ocean following Shankar, Vinayachandran, and Unnikrishnan (2002). Along the south-west coast of India, equatorward components of wind lead to the offshore Ekman transport and upwelling, while the poleward wind favors onshore transport and downwelling. Hence, offshore and onshore Ekman mass transports are represented by negative and positive values, respectively. Using conventional methods, positive values of Ekman pumping represent upward velocity and negative values represent downward velocity. Convergence of surface waters marks the areas of coastal downwelling distinguished by sea surface elevation than the surrounding waters and upwelling areas are characterized by fall in sea level due to the presence of cooler/denser sub-surface waters. Horizontal divergence calculated from the zonal and meridional components of currents integrated over the surface to $100 \mathrm{~m}$ depth level is also used to identify the possible driving forces of upwelling and downwelling other than from the wind forcing. 


$$
\nabla \cdot V=\left(\frac{\partial u}{\partial x}+\frac{\partial v}{\partial y}\right)
$$

where $\nabla . V$ represents the horizontal divergence and $u$ and $v$ are the zonal and meridional component of current velocity. All the above-mentioned data are converted to climatology for the present study.

\section{Results and discussion}

\section{Vertical distribution of isotherms}

Vertical distribution of isotherms manifests a significant seasonal oscillation along the south-west coast of India during the year (Figure 2). An upward shift commenced at the subsurface level (below $100 \mathrm{~m}$ ) during March/April and it was noticeable from May. During the peak summer monsoon months July and August, this vertical movement was intensified and reached the surface level (Figure $2(\mathrm{a}, \mathrm{b}, \mathrm{c})$ ). The mean vertical velocity calculated along the southwest coast of India from the vertical shift of $26^{\circ} \mathrm{C}$

(a) $(8.5 \mathrm{~N})$

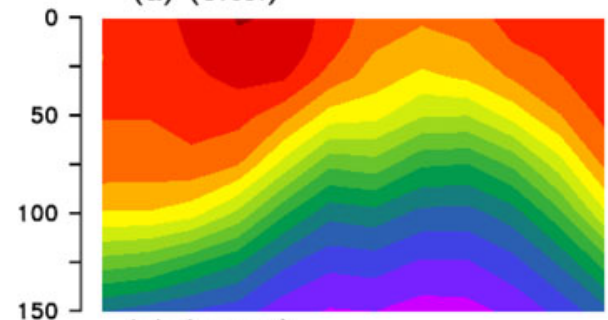

(c) $(12.5 \mathrm{~N})$

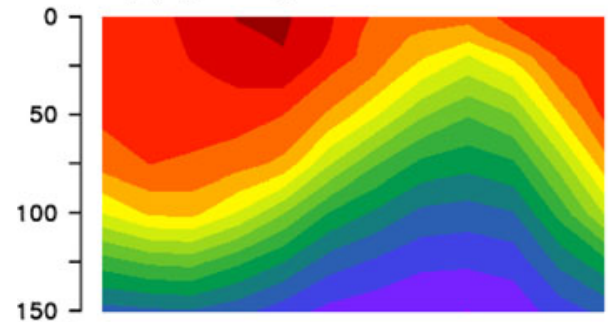

(e) $(14.5 \mathrm{~N})$ (b) $(10.5 \mathrm{~N})$

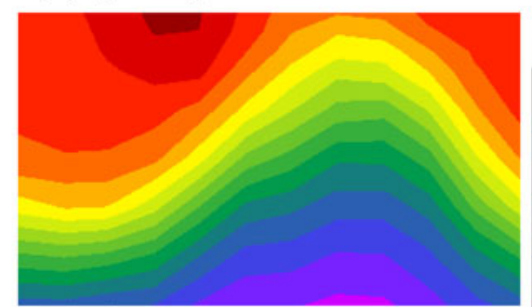

(d) $(13.5 \mathrm{~N})$

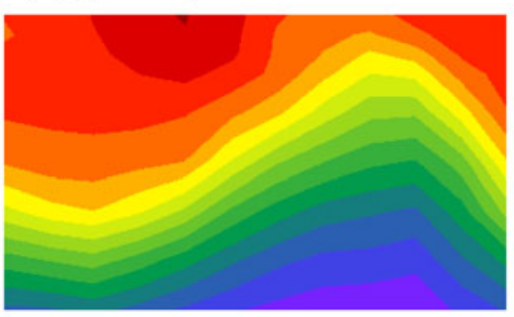

(f) $(15.5 \mathrm{~N})$

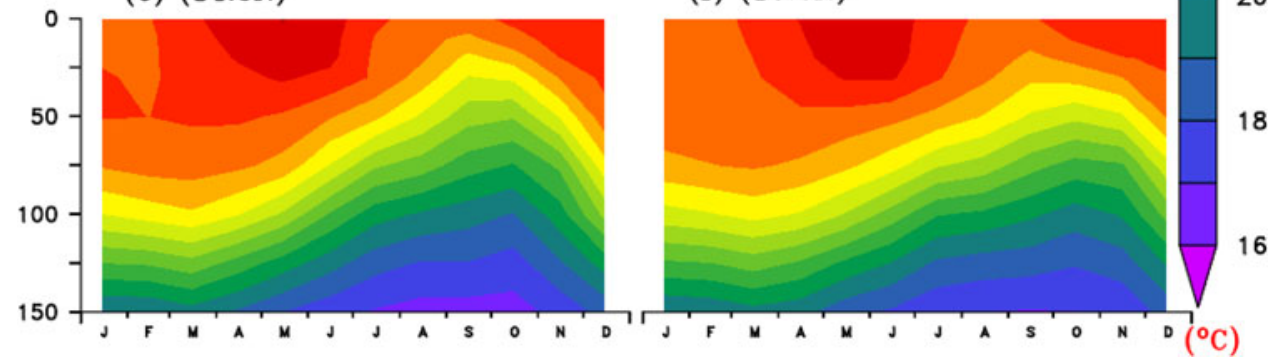

Figure 2. Vertical oscillation of isotherms [between surface and $150 \mathrm{~m}$ depth] at particular latitudes along the south-west coast of India from January to December [climatology]. 
isotherms from May to August was $0.57 \mathrm{~m} /$ day $\left(6.62 \times 10^{-6} \mathrm{~m} / \mathrm{s}\right)$. Hu and Wang (2016) revealed an upward movement of sea water with a speed ranging from about $10^{-6}$ to $10^{-4} \mathrm{~m} / \mathrm{s}$ is referred as upwelling. The calculated velocity along the south-west coast of India falls in the upwelling band. Comparison of Figure 2(a) and (f) reveals the significant delay observed in the evolution of upwelling at $8.5^{\circ} \mathrm{N}$ and $15.5^{\circ} \mathrm{N}$. This hints at the propagation of upwelling from southern latitudes to northern latitudes.

From October onwards, the uplifted isotherms tend to move downwards intensifying during December to February. The mean downward velocity calculated from the downward shift of $26^{\circ} \mathrm{C}$ isotherms from October to January is $-0.698 \mathrm{~m} /$ day $\left(8.08 \times 10^{-6} \mathrm{~m} / \mathrm{s}\right)$ along the south-west coast of India.

\section{Sea surface height anomaly (SSHA) and depth of $26^{\circ} \mathrm{C}$ isotherms (D26)}

To substantiate the findings on upwelling and downwelling from the vertical movement of isotherms, the present study also analyses the intra annual variability of SSHA and D26 along the south-west coast of India (Figure 3). During the summer monsoon from May to September D26 and SSHA significantly decreased along the study area, a strong indication of upwelling. The south-north propagation in D26 (Figure 3(a)) and SSHA (Figure 3(b)) also displays the delayed intensification of upwelling at the northern latitude $\left(15.5^{\circ} \mathrm{N}\right)$ compared with the south $\left(8.5^{\circ} \mathrm{N}\right)$. During October both SSHA and D26 tend to set back and by the arrival of north-east monsoon during November they start to rise along the coast. It was also inferred that downwelling along the coast was intensified during December to January.

\section{Prevailing wind and Ekman drift over the eastern Arabian Sea}

Figure 4 shows the magnitude and direction of wind stress vectors over the eastern Arabian Sea. During the summer monsoon from May to September strong southwesterly or westerly winds are blowing over the eastern Arabian Sea (Figure 4, upper panel). During this period the Ekman drift was equatorward and the maximum strength was observed during June to August (Figure 4, lower panel). Strong Ekman drift during this period supports substantial vertical motion along the coastal region. Throughout the northeast monsoon and winter from November to February, these southwesterly and westerly winds during the summer monsoon reverse their directions to northeasterly or northerly along the south-west coast of India (Figure 5, upper panel). These winds are parallel to the coast during January and February. The Ekman drift along the south-west coast of India was feeble during November and December (Figure 5, lower panel). The 
(a)
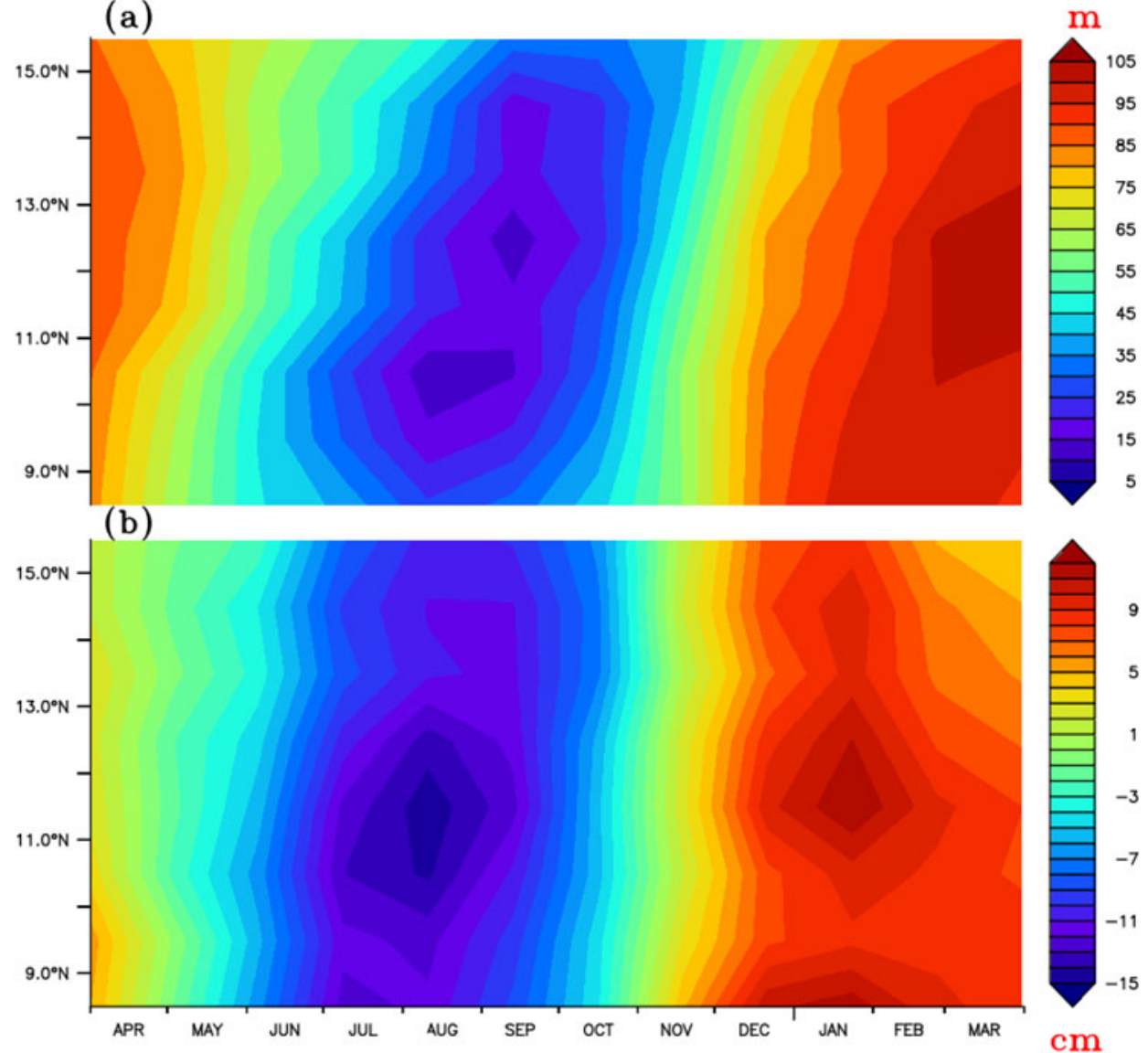

Figure 3. Intra annual variability of (a) depth of $26^{\circ} \mathrm{C}$ isotherms (m) and (b) sea surface height anomaly $(\mathrm{cm})$ along the south-west coast of India from April to March in climatological axis [SSHA and D26 are averaged over the grids shown in Figure 1 and represented from $8.5^{\circ} \mathrm{N}$ to $\left.15.5^{\circ} \mathrm{N}\right]$.

coast was characterized by weak offshore drift during January and February and it was not favorable for downwelling but conducive to weak upwelling. The analysis of wind and Ekman drift over the eastern Arabian Sea reveals that compared with south-west monsoon wind and Ekman drift, the wind during north-east monsoon and winter unable to drive strong vertical motion along the south-west coast of India.

\section{Ekman transport due to alongshore component of wind}

Most previous studies on vertical circulation along the south-west coast of India treated the offshore transport due to the alongshore component of wind as the primary driving force for upwelling. Here, we have attempted to check whether this assumption is consistent with the facts relating to the vertical circulation along the west coast of India. Figure 6 shows the surface 

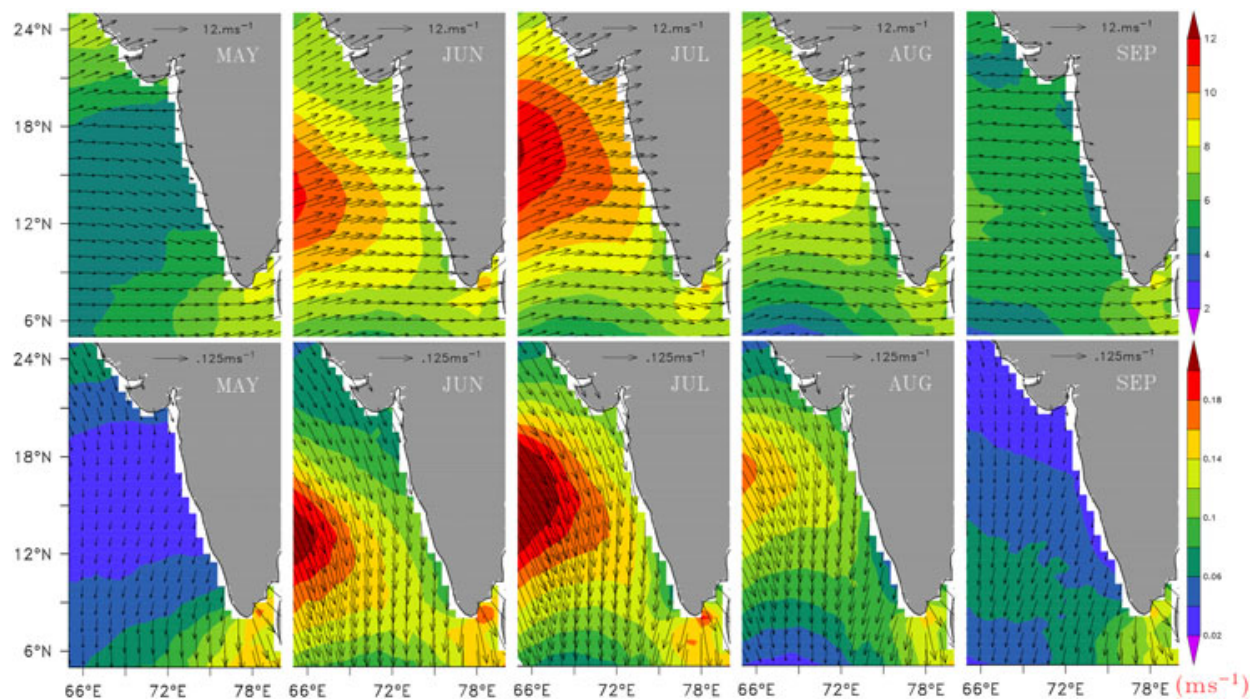

Figure 4. Prevailing wind (upper panel) and depth mean Ekman drift (lower panel) over the eastern Arabian Sea during the south-west monsoon.
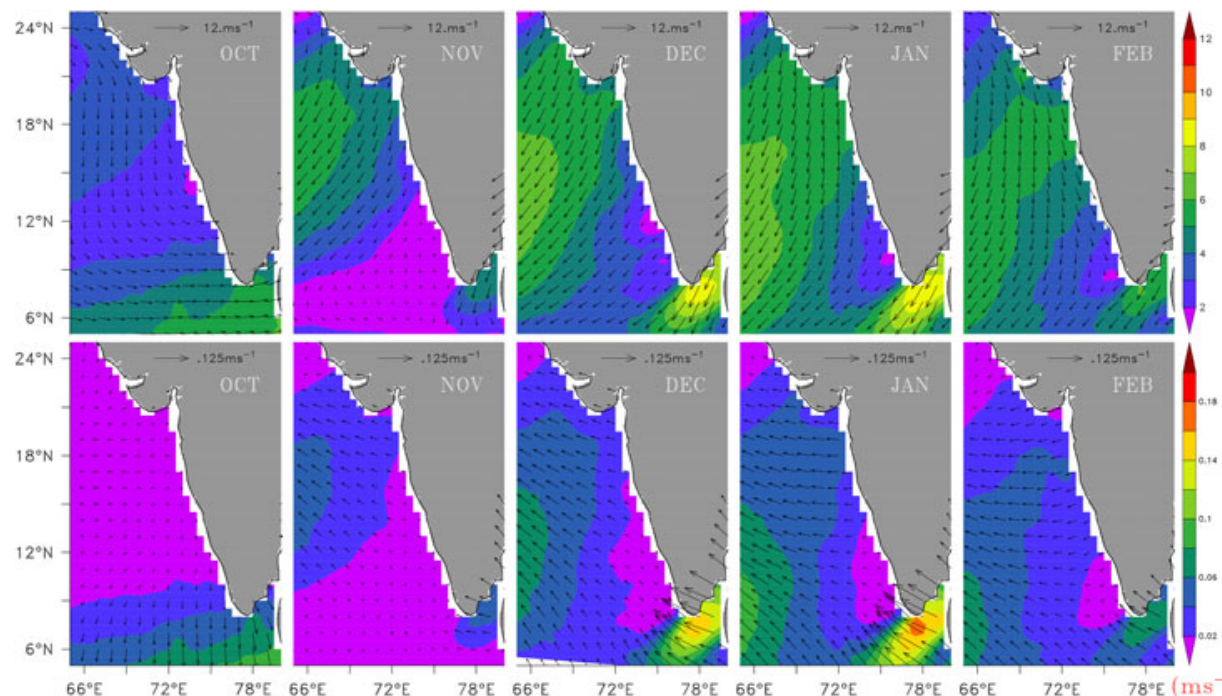

Figure 5. Prevailing wind (upper panel) and depth mean Ekman drift (lower panel) over the eastern Arabian Sea during the north-east monsoon and winter.

mass transport due to the alongshore component of wind over the study region. Along the south-west coast of India, upwelling favorable offshore Ekman transport is westward and it is represented by negative values. Subsequently, downwelling favorable onshore Ekman transport is represented by positive values. From Figure 6, it can be deduced that along the south-west coast of India, throughout the year except the summer monsoon months, the coast was characterized by weak to moderate 


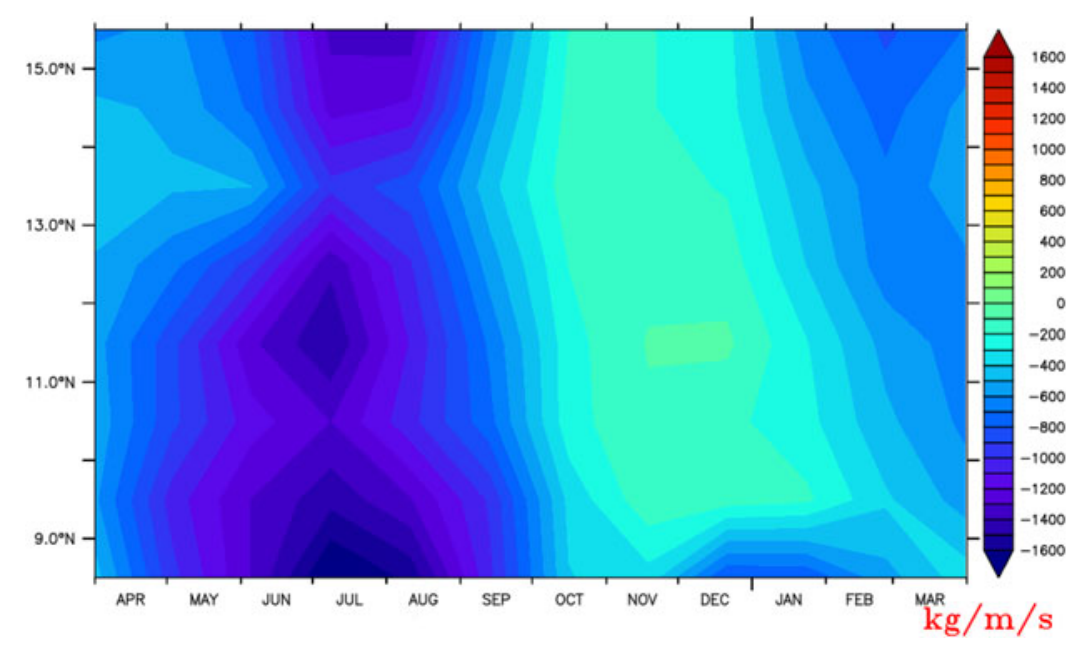

Figure 6. Intra annual variability of Ekman mass transport $(\mathrm{kg} / \mathrm{m} / \mathrm{s})$ due to the alongshore component of wind along the south-west coast of India from April to March in climatological axis [Ekman transport is averaged over the grids shown in Figure 1 and represented from $8.5^{\circ} \mathrm{N}$ to $\left.15.5^{\circ} \mathrm{N}\right]$.

Table 2. Ekman transport $(\mathrm{kg} / \mathrm{m} / \mathrm{s})$ due to the alongshore component of wind along the south-west coast of India during the north-east monsoon and winter.

\begin{tabular}{lcccc}
\hline Latitude $\left({ }^{\circ} \mathrm{N}\right)$ & November & December & January & February \\
\hline 8.5 & -341 & -811 & -791 & -540 \\
9.5 & -131 & -149 & -179 & -384 \\
10.5 & -116 & -173 & -266 & -477 \\
11.5 & -93 & -81 & -293 & -535 \\
12.5 & -127 & -148 & -401 & -657 \\
13.5 & -159 & -209 & -464 & -674 \\
14.5 & -192 & -261 & -568 & -742 \\
15.5 & -192 & -272 & -655 & -821 \\
\hline
\end{tabular}

upwelling-favorable offshore transport (weak negative values). But during the peak summer monsoon strong offshore transport was observed along the southwest coast having difference in magnitude from south to north. Along the coast, the average value of surface transport is $-1339 \mathrm{~kg} / \mathrm{m} / \mathrm{s}$ (offshore) during July and $-413 \mathrm{~kg} / \mathrm{m} / \mathrm{s}$ (offshore) during January. Table 2 represents the Ekman mass transport during the north-east monsoon and winter.

\section{Ekman pumping}

Figure 7(c) represents the monthly variability of Ekman pumping velocity derived from the divergence of Ekman mass transport along the south-west coast of India. Strong upward velocity (positive values) was witnessed along the coastal grids from $8.5^{\circ} \mathrm{N}$ to $12.5^{\circ} \mathrm{N}$ during May to September. Above $12.5^{\circ} \mathrm{N}$, moderate values were observed. During the north-east monsoon 


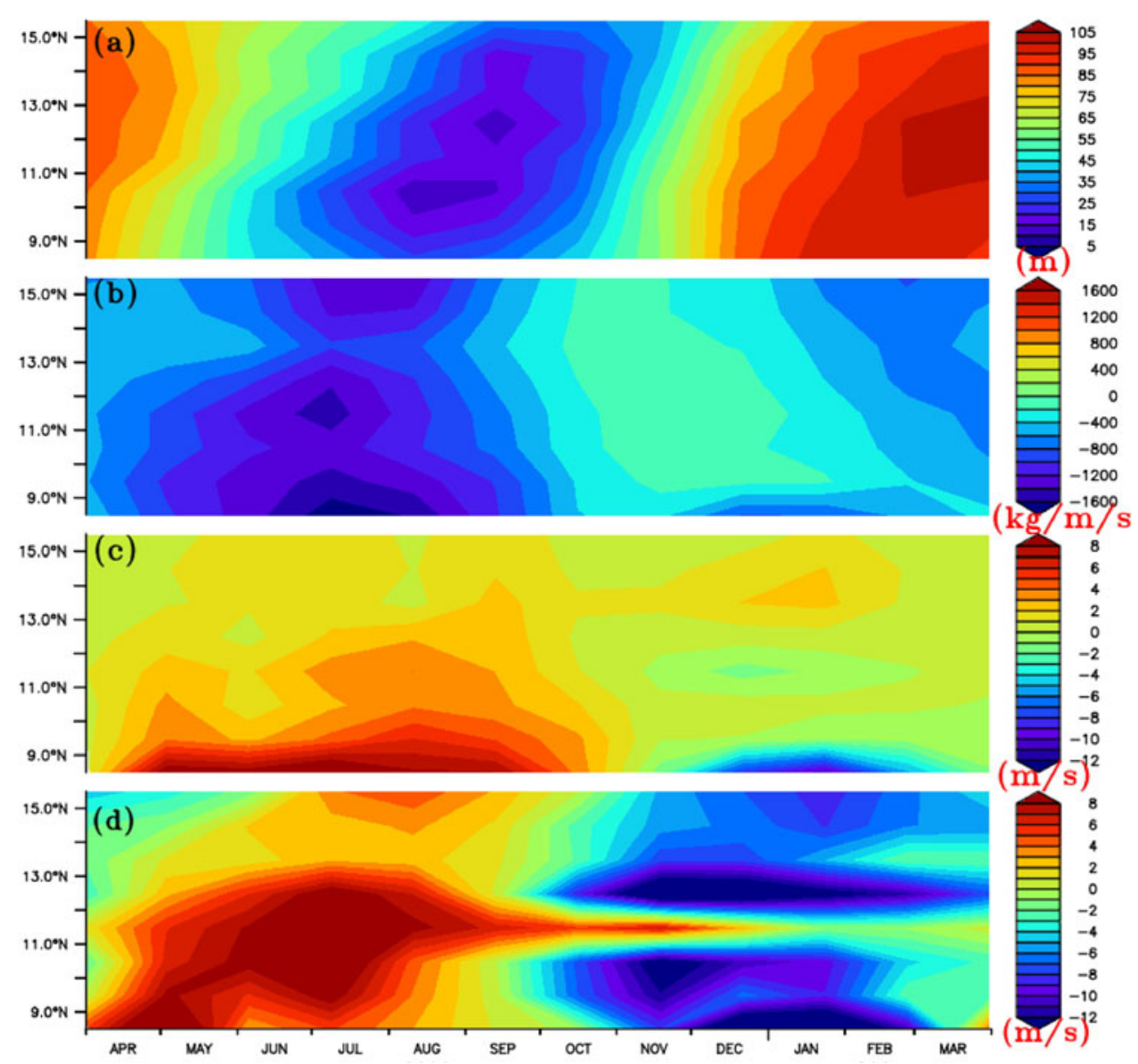

Figure 7. Intra annual variability of (a) D26 (m) (b) Ekman transport due to alongshore wind $(\mathrm{kg} / \mathrm{m} / \mathrm{s})$ (c) Ekman pumping velocity $(\mathrm{m} / \mathrm{s}) \times 10^{-6}$ and (d) surface to $100 \mathrm{~m}$ depth integrated divergence of currents $(\mathrm{m} / \mathrm{s}) \times 10^{-6}$ along the south-west coast of India.

and winter except at $8.5^{\circ} \mathrm{N}$ to $9.5^{\circ} \mathrm{N}$ and $11.5^{\circ} \mathrm{N}$, the coast was characterized by weak upward velocity. Along the southern latitudes at $8.5^{\circ} \mathrm{N}$ and $9.5^{\circ} \mathrm{N}$ strong downward velocity was observed. From Table 3, it was evident that Ekman pumping along the coast was stronger along the southern latitudes compared with north during both seasons. It was also inferred that upwelling favorable environments existed along the south-west coast throughout the year even though the observations on vertical distribution of isotherms and D26 were contrary to it.

\section{Divergence of currents}

Since the depth of $26^{\circ} \mathrm{C}$ isotherms varies between 5 and $105 \mathrm{~m}$ depth along the south-west coast of India from January to December (Figure 3(a)), divergence calculated along the west coast of India was integrated over 
Table 3. Ekman pumping velocity $(\mathrm{m} / \mathrm{s})$ along the south-west coast of India.

\begin{tabular}{lcccr}
\hline & \multicolumn{3}{c}{ Months } \\
\cline { 2 - 5 } Latitude $\left({ }^{\circ} \mathrm{N}\right)$ & July & August & December & January \\
\hline 8.5 & 10.52 & 8.23 & -8.21 & -10.72 \\
9.5 & 4.288 & 6.07 & -0.061 & -0.923 \\
10.5 & 2.805 & 3.831 & 0.54 & 0.336 \\
11.5 & 3.56 & 4.007 & -1.467 & -0.768 \\
12.5 & 2.176 & 2.903 & 0.467 & 0.537 \\
13.5 & 1.449 & 0.695 & 2.029 & 2.275 \\
14.5 & 1.863 & 0.954 & 1.505 & 2.043 \\
15.5 & 1.599 & 0.81 & 0.483 & 1.31 \\
\hline
\end{tabular}

The values shown in the table need to multiply by $10^{-6}$.

surface to $100 \mathrm{~m}$ depth. Intra annual variability of this depth integrated divergence is shown in Figure $7(\mathrm{~d})$. During the summer monsoon from May to September south-west coast of India was characterized by strong divergence (positive values). Compared to northern latitudes divergence along $8.5^{\circ} \mathrm{N}$ to $13^{\circ} \mathrm{N}$ was much stronger. This strong divergence leads to strong upwelling along the coast during the summer monsoon. Contrary to wind forcing, divergence of currents along the coastal grids during the north-east monsoon and winter exhibits significant convergent fields (negative values) which are conducive for downwelling. Values of depth integrated divergence are listed in Table 4 for the comparison of southern and northern latitudes. Along the south-west coast of India, except at $11.5^{\circ} \mathrm{N}$, convergence during the north-east monsoon and winter is stronger in magnitude compared with divergence during the summer monsoon.

Based on several previous studies, the plausible explanation for upwelling and downwelling along the west coast of India was linked to Ekman mass transport and Ekman pumping. Hence, we analyzed these processes along the west coast of India during both monsoons and transition periods. Since the upwelling and downwelling areas are characterized by the upward and downward movement of isotherms, and the vertical motion is driven mainly by Ekman mass transport, Ekman pumping and divergence of currents. We pool the findings on upwelling and downwelling in Figure 7. The analysis also reveals that south-west coast of India was characterised by upwelling during summer monsoon and by downwelling during northeast monsoon and winter. Hence, an average from June to September and November to February of all the above-mentioned parameters are discussed in Figure 8 for the better understanding of forcing involved in the vertical motion along the south-west coast of India.

The overall analysis of Ekman transport and Ekman pumping velocity reveals that south-west coast of India was characterized by strong offshore Ekman transport and upward Ekman pumping during the south-west monsoon from May to September (Figures $7(b, c)$ and $8(b, c)$ ). This was conducive for upwelling and it was well displayed in the distribution of D26 
Table 4. Divergence of currents [depth integrated from surface to $100 \mathrm{~m}$ depth] along the south-west coast of India.

\begin{tabular}{lcccc}
\hline & \multicolumn{4}{c}{ Months } \\
\cline { 2 - 5 } Latitude $\left({ }^{\circ} \mathrm{N}\right)$ & July & August & December & January \\
\hline 8.5 & 5.07 & 2.97 & -17.15 & -16.97 \\
9.5 & 8.86 & 3.87 & -6.49 & -8.93 \\
10.5 & 11.11 & 4.55 & -10.72 & -9.58 \\
11.5 & 9.78 & 8.467 & 2.79 & -1.11 \\
12.5 & 9.38 & 6.97 & -15.57 & -13.25 \\
13.5 & 2.875 & 2.383 & -7.758 & -4.99 \\
14.5 & 2.489 & 3.271 & -6.263 & -8.065 \\
15.5 & 3.851 & 9.742 & 6.977 & -8.586 \\
\hline
\end{tabular}

The values shown in the table need to multiply by $10^{-6,}$ the value at $10.5^{\circ} \mathrm{N}$ and $12.5^{\circ} \mathrm{N}$ are calculated with an extension of $0.5^{\circ}$ offshore from the coastal grids.

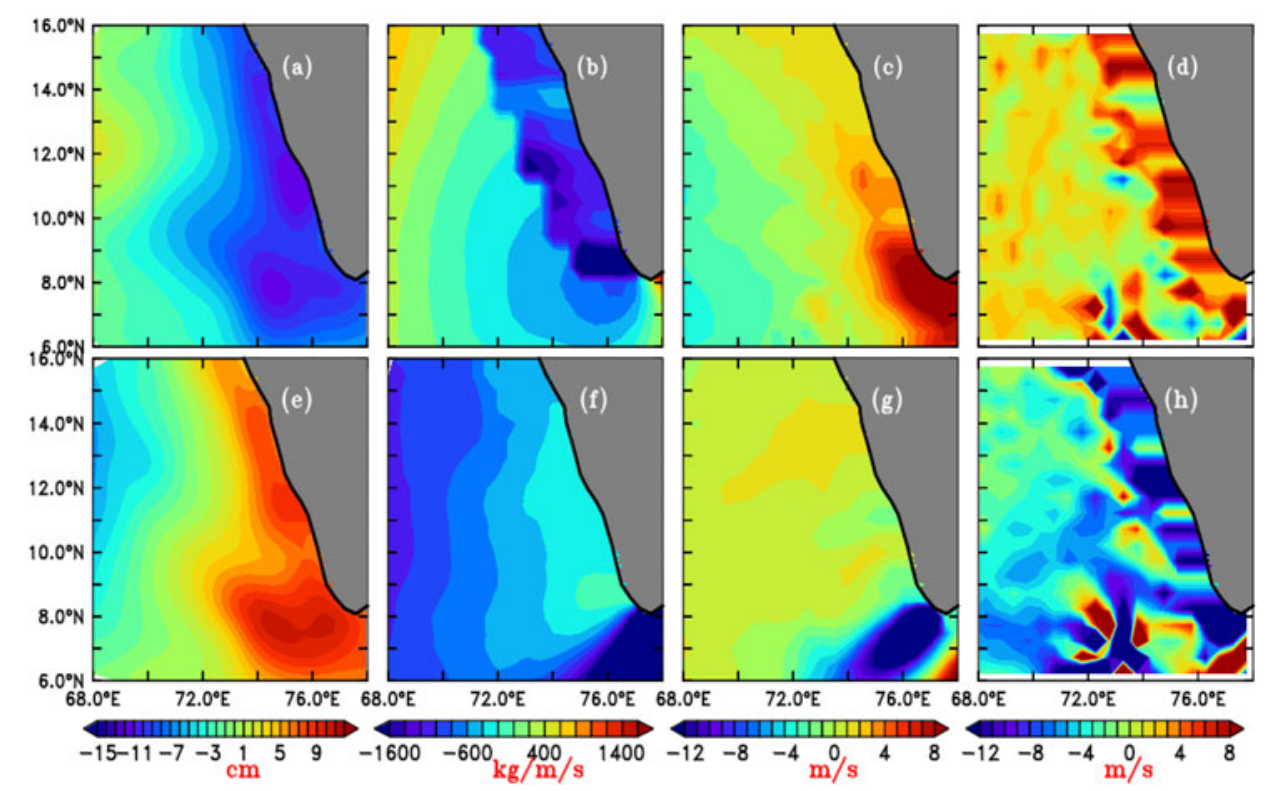

Figure 8. June to September average of (a) SSHA (cm), (b) Ekman transport $(\mathrm{kg} / \mathrm{m} / \mathrm{s})$, (c) Ekman pumping velocity $(\mathrm{m} / \mathrm{s}) \times 10^{-6}$, (d) depth integrated divergence $(\mathrm{m} / \mathrm{s}) \times 10^{-6}$ and $(\mathrm{e}-\mathrm{h})$ November to February average of the above-mentioned parameter.

(Figure 7(a)). During this period D26 shows lower values and it represents well the uplifted $26^{\circ}$ isotherms. This indicates that along the southwest coast of India, wind played a significant role in upwelling. During May to September, wind is favorable for upwelling and it is well correlated with the surface manifestation of upwelling along the south-west coast.

During the north-east monsoon and winter (November to February), the coast also exhibits weak to moderate offshore transport and upward Ekman pumping velocity (Figures $7(\mathrm{~b}, \mathrm{c})$ and $8(\mathrm{f}, \mathrm{g})$ ). If the assumption that the Ekman transport due to the alongshore wind stress and Ekman pumping is sufficient to explain upwelling and downwelling along west coast of India were correct, then from the above analysis we would expect weak-to- 
moderate upwelling along the entire west coast throughout the northeast monsoon, winter and transition periods. But our findings on the period and area of upwelling from the vertical distribution of isotherms and SSHA were completely contradictory to the above expectation (Figures 7(a) and 8(e)). During the north-east monsoon and winter, the coast manifested a strong rise in sea level and D26 due to downwelling. On the basis of this discussion, we assert that the Ekman mass transport due to the alongshore wind stress and Ekman pumping alone is not enough to explain thoroughly and completely the upwelling and downwelling phenomena along the west coast of India.

We also analyzed the depth integrated divergence due to the currents along the west coast of India throughout the year. During the summer monsoon, the southwest coast of India was characterized by strong horizontal divergence from May to September (Figures $7(\mathrm{~d})$ and $8(\mathrm{~d})$ ) and showed a decreasing trend from south to north. SSHA and D26 also substantiate the above finding. Hence, strong upwelling along the southwest coast of India during the peak summer monsoon is due to the combined effects of current-induced horizontal divergence and wind-induced Ekman pumping and offshore mass transport.

During the northeast monsoon and winter, the west coast of India was characterized by moderate-to-strong convergence (Figures $7(\mathrm{~d})$ and $8(\mathrm{~h})$ ) and the magnitude of convergence was stronger than the divergence during the summer monsoon. Compared with the north, the magnitude of convergence was stronger over the southern latitudes. Even though the windinduced surface mass transport did not favor downwelling along the west coast of India during the winter season, the convergence due to the surface currents did induce downwelling. This is the basis for downwelling along the west coast of India. Even though wind does not support convergence during this period, the coast was characterized by strong convergence, indicating the influence of remote forcing on both horizontal and vertical circulation along the west coast of India.

\section{Influence of remote forcing on upwelling and downwelling}

Kelvin waves are a special type of gravity wave, constrained by Earth's rotation and characterized by unidirectional propagation that may be trapped at the Equator or along the vertical boundaries such as coastlines (Gill 1982; Wang 2002). Several previous authors have investigated the propagation of coastally trapped waves in the boundaries of the world ocean and associated energy leakage from the eastern boundary to the west. While explaining the dynamics of California current system, Marchesiello, McWilliams, and Shchepetkin (2003) reveals the eastern boundary 
upwelling energy leaks through the radiation of Rossby waves. Whereas upwelling along the western boundaries, noticeably in the Arabian Sea, are forced by the Rossby wave leakages from the eastern Arabian Sea (Vic et al. 2017). A detailed theoretical background for the energy leakage from the eastern boundaries was provided by Grimshaw and Allen (1988) and by Clarke and Shi (1991).

While describing the offshore penetration of Rossby waves at $15^{\circ} \mathrm{N}$ along the west coast of India, Vialard et al. (2009) calculated the critical period using the first baroclinic mode Kelvin wave velocity provided by Chelton et al. (1998). To check the remote effects of wind blowing over the north Indian Ocean on the sea level variability along the south-west coast of India due to the generation of boundary-trapped Kelvin waves, initially both data sets were band passed based on the critical period information provided by Vialard et al. (2009). Then a lag correlation was done between daily zonal winds over the entire north Indian Ocean and daily SSHA along the southwest coast of India, following the approach of Gopalakrishna et al. (2008) and Hareesh Kumar and Anand (2016). Daily SSHA and zonal winds for the years 2009-2014 was used for the spatial correlation.

The spatial correlation between box-averaged SSHA $\left(7^{\circ} \mathrm{N}-9^{\circ} \mathrm{N}\right.$ and $76^{\circ} \mathrm{E}-77^{\circ} \mathrm{E}$ ) at the southern tip of west coast of India and zonal wind over the entire north Indian Ocean is mapped in Figure 9. A significant positive correlation was evident over the eastern equatorial Indian Ocean with a lag of 32-52 days and the correlation diminished after this period over the equatorial region. It indicates the influence of zonal winds over the equatorial Indian Ocean on SSHA along the west coast of India.
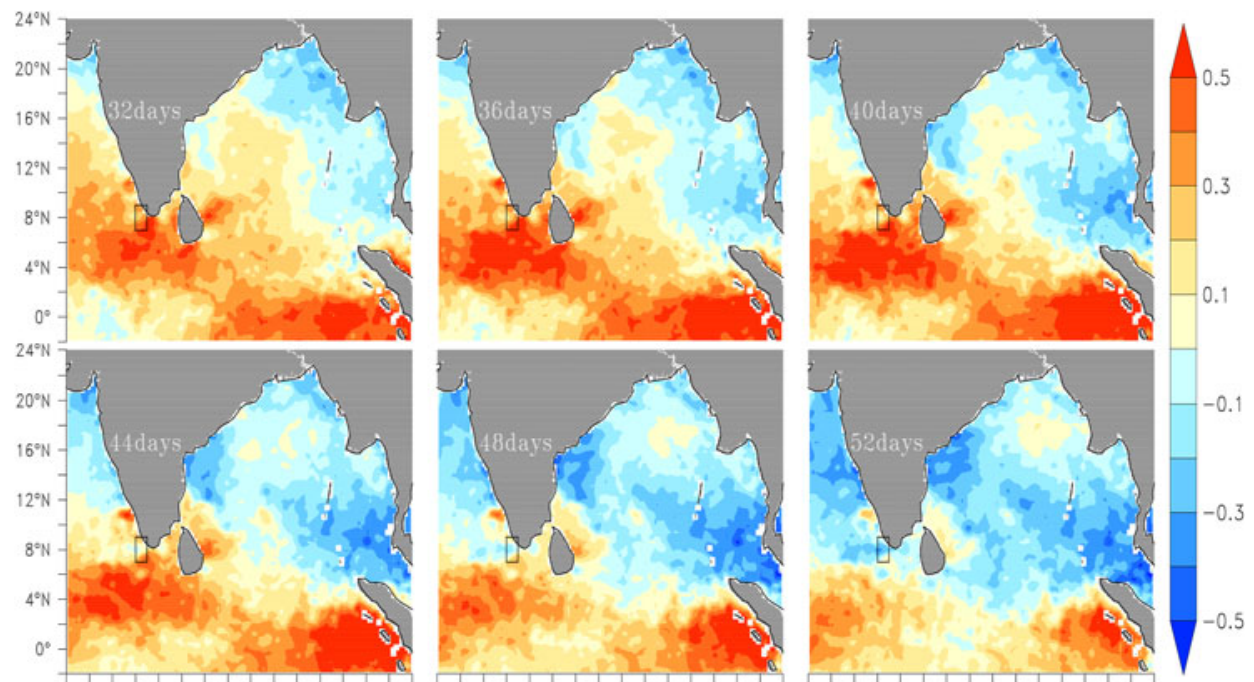

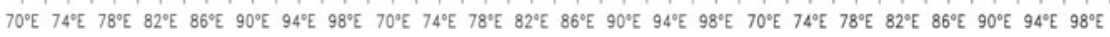

Figure 9. Lag correlation (32-52) days between SSHA in the coastal box $\left[7^{\circ} \mathrm{N}: 9^{\circ} \mathrm{N}\right.$ and $76^{\circ} \mathrm{E}$ : $\left.77^{\circ} \mathrm{E}\right]$ and zonal wind over the rest of the basin. 


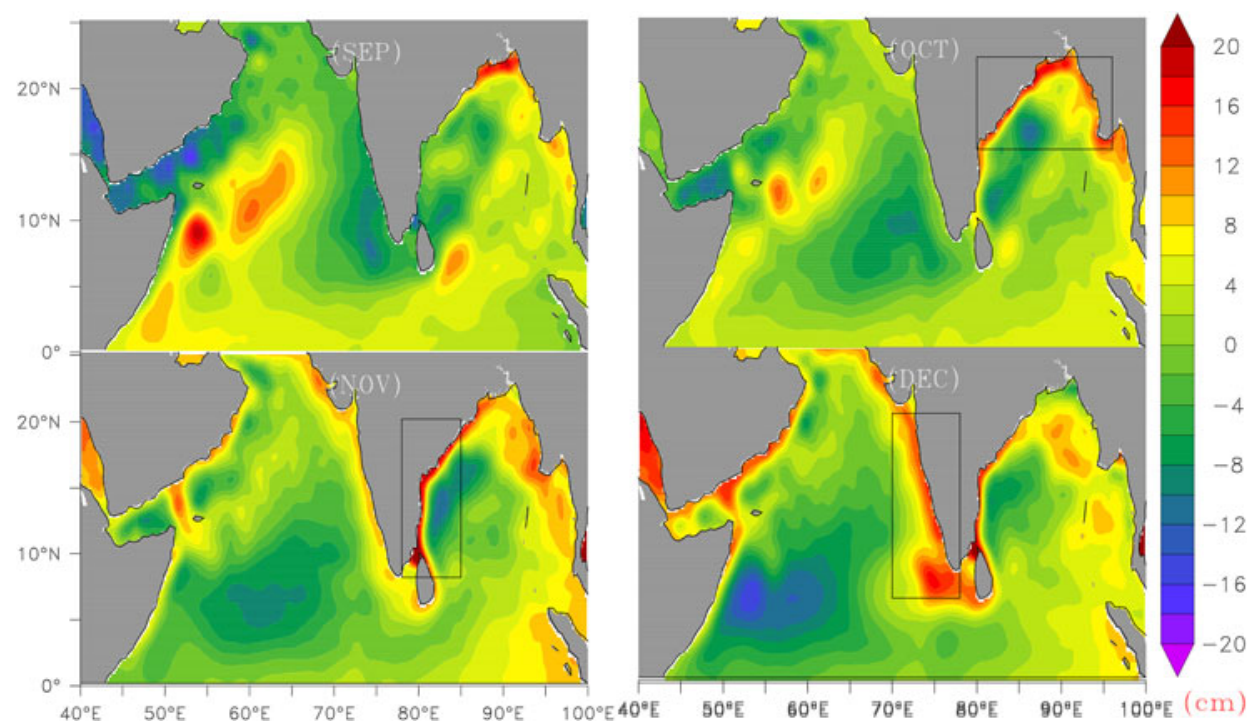

Figure 10. Monthly climatology of SSHA $(\mathrm{cm})$ over the north Indian Ocean during September to December [propagation of Kelvin waves along the coastal wave guides of Bay of Bengal and reaches the west coast of India during December are shown in boxes].

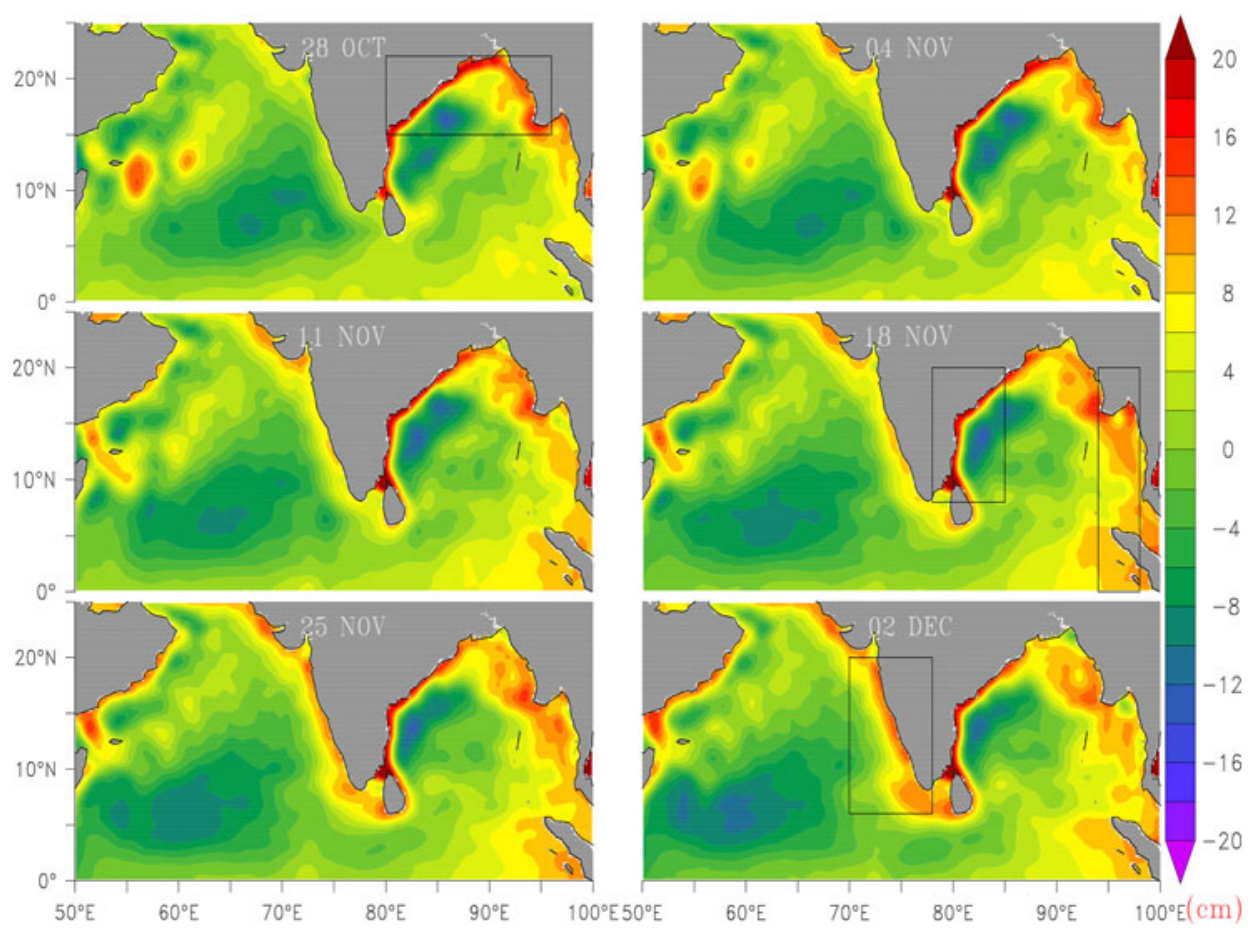

Figure 11. Weekly climatology of SSHA $(\mathrm{cm})$ over the north Indian Ocean from 28th October to 2nd December [propagation of Kelvin waves along the coastal wave guides of Bay of Bengal and reaches the west coast of India during December are shown in boxes]. 


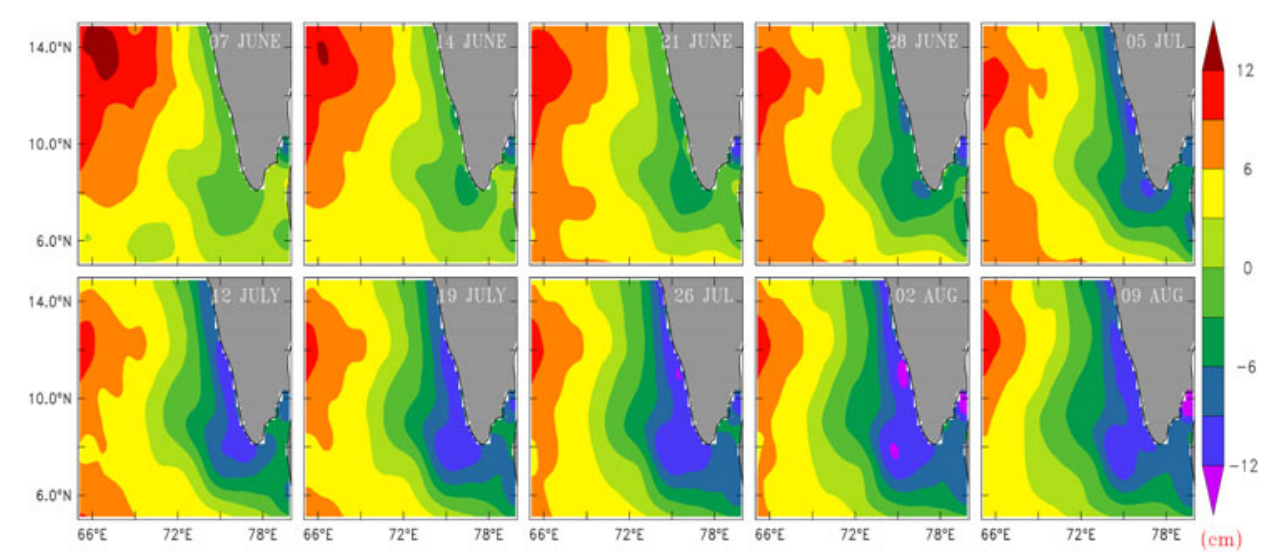

Figure 12. Weekly climatology of SSHA (cm) along the west coast of India during the summer monsoon from 7 th June to 9 th August.

The monthly and weekly climatology of SSHA over the north Indian Ocean during October to December are shown in Figures 10 and 11, respectively. These figures show the propagation of positive SSHA through the wave guides of equator and Bay of Bengal to the west coast of India. This is confirmed that the Kelvin waves propagated from the equator and Bay of Bengal are eventually reached the Arabian Sea during the northeast monsoon season and winter. Further, the presence of this Kelvin waves cause downwelling along the west coast of India during the winter and northeast monsoon period, even though the wind does not support the downwelling process

The present study also confirmed a significant negative correlation at the Gulf of Mannar region and south of Srilanka with 8-12 days lag as indicated in the studies of Gopalakrishna et al. (2008) and Hareesh Kumar and Anand (2016). A negative SSHA that propagated from the southern tip to the entire south-west coast of India during July and August represents the upwelling mode of Kelvin wave (Figure 12).

\section{Conclusion}

In this study, a climatology-based analysis of various physical oceanographic parameters is attempted to understand the annually recurrent upwelling and downwelling phenomena along the south-west coast of India. The main findings of the paper are listed below.

- Upwelling along the south-west coast of India starts at the subsurface level during March/April at the southern tip of India and it is intensified from May to September during the south-west monsoon. 
- Upwelled water reaches the surface during July and August.

- A noticeable delay was observed in the intensification of upwelling from $8^{\circ} \mathrm{N}$ to $16^{\circ} \mathrm{N}$ along the south-west coast of India.

- Upwelling was more dominant along the southern latitudes compared to north.

- Strong Ekman drift was observed along the south-west coast of India during the summer monsoon to drive significant vertical circulation along the coast.

- Upwelling along the south-west coast of India was driven mainly by the combined effect of Ekman transport due to the alongshore wind, Ekman pumping, divergence of currents and due to the propagation of coastally trapped waves from the Gulf of Mannar region and south of Srilanka.

- Downwelling along the coast was intensified during November to February, when the north-east monsoon advances along the coast.

- Like upwelling, downwelling was more dominant along the southern latitudes.

- Ekman drift during the north-east monsoon and winter is too weak to drive any significant vertical circulation along the coast.

- The south-west coast of India experiences downwelling during November to February, when Ekman transport and pumping are conducive to weak upwelling.

- Divergence of currents associated with the propagation of coastally trapped Kelvin waves from the equator played a significant role in driving the downwelling along the south-west coast of India.

- Along the south-west coast of India, the average vertical velocity calculated from the vertical shift of isotherms is $0.57 \mathrm{~m} /$ day during upwelling and is $0.69 \mathrm{~m}$ /day during downwelling

\section{Acknowledgments}

The manuscript is a part of the Ph.D. thesis of the first author. Authors would like to acknowledge National Institute of Oceanography and A. Chatterjee for the temperature and salinity climatology of north Indian Ocean. Asia Pacific Data Research Centre is thanked for altimeter data distributed by AVISO and for SODA Ocean currents. The authors acknowledge Department of Physical Oceanography, CUSAT, Kochi and Director, CMFRI, Kochi for the support provided.

\section{Funding}

The authors are thankful to INCOIS, Ministry of Earth Sciences, Govt. of India for the funding provided. The authors are also thankful to Department of Science and Technology, Govt. of India for the Jawaharlal Nehru Science Fellowship and SPLICE- Climate Change Programme. 


\section{References}

Antony, M. K., S. G. Narayana, and Y. K. Somayajulu. 2002. Offshore limit of coastal ocean variability identified from hydrography and altimeter data in the Eastern Arabian Sea. Continental Shelf Research 22:525-2536.

Banse, K. 1959. On upwelling and bottom trawling off the southwest Coast of India. Journal of the Marine Biological Association of India 1:33-49.

Banse, K. 1968. Hydrography of the Arabian Sea shelf of India and Pakistan and effects on demersal fishes. Deep Sea Research 15:45-79.

Carton, X., P. L'Hegaret, and R. Baraille. 2012. Mesoscale variability of water masses in the Arabian Sea as revealed by ARGO floats. Ocean Science 8(2):227-248.

Chatterjee, A., D. Shankar, S. S. C. Shenoi, G. V. Reddy, G. S. Michael, M. Ravichandran, V. V. Gopalkrishna, E. P. Rama Rao, T. V. S. Udaya Bhaskar, and V. N. Sanjeevan. 2012. A new atlas of temperature and salinity for the North Indian Ocean. Journal of Earth System Science 121 (3):559-593.

Chelton, D. B., R. A. Deszoeke, M. G. Schlax, K. El Naggar, and N. Siwertz. 1998. Geographical variability of the first baroclinic Rossby radius of deformation. Journal of Physical Oceanography 28 (3):433-460.

Clarke, A. J. 1983. The reflection of equatorial waves from oceanic boundaries. Journal of Physical Oceanography 13 (7):1193-1207.

Clarke, A. J., and C. Shi. 1991. Critical frequencies at ocean boundaries. Journal of Geophysical Research 96 (C6):10731-10738.

Gill, A. E. 1982. Atmosphere-ocean dynamics. Elsevier.

Gopalakrishna, V. V., R. R. Rao, K. Nisha, M. S. Girish Kumar, T. Pankajackshan, M. Ravichandran, Z. Johnson, K. Girish, N. Aneeshkumar, M. Srinath., et al. 2008. Observed anomalous upwelling in the Lakshadweep Sea during the summer monsoon season of 2005. Journal of Geophysical Research 113 (C5):1-12.

Grimshaw, R., and J. S. Allen. 1988. Low-frequency baroclinic waves off coastal boundaries. Journal of Physical Oceanography 18 (8):1124-1143.

Hareesh Kumar, P. V., and P. Anand. 2016. Coastal upwelling off the southwest Coast of India: observations and simulations. International Journal of Digital Earth 9 (12): 1256-1274.

Hu, J., and X. H. Wang. 2016. Progress on upwelling studies in the China seas. Reviews of Geophysics 54 (3):653-673.

Jayaram, C., N. Chacko, K. A. Joseph, and A. N. Balchand. 2010. Interannual variability of upwelling indices in the Southeastern Arabian Sea: a satellite-based study. Ocean Science Journal 45 (1):27-40. doi:10.1007/s12601-010-0003-6.

Johannessen, O. M., G. Subbaraju, and J. Blindheim. 1987. Seasonal variation of oceanographic conditions off the southwest Coast of India during 1971-1975. Fiskeridirektoratets skrifter, Serie Havundersøkelser 18:247-261.

Luis, A. J., and H. Kawamura. 2004. Air-sea interaction, coastal circulation and biological production in the Eastern Arabian Sea: A review. Journal of Oceanography 60 (2): 205-218.

Madhupratap, M., S. P. Kumar, P. M. A. Bhattathiri, M. D. Kumar, S. Raghukumar, K. K. C. Nair, and N. Ramaiah. 1996. Mechanism of the biological response to winter cooling in the northeastern Arabian Sea. Nature 384 (6609):549-552.

Madhupratap, M., S. R. Shetye, K. N. V. Nair, and S. R. Sreekumaran Nair. 1994. Oil sardine and Indian mackerel: Their fishery, problems and coastal oceanography. Current Science 66 (5):340-348. 
Marchesiello, P., J. C. McWilliams, and A. Shchepetkin. 2003. Equilibrium structure and dynamics of the California current system. Journal of Physical Oceanography 33 (4):753-783.

McCreary, J. P., W. Han, D. Shankar, and S. R. Shetye. 1996. Dynamics of the east India coastal current: 2. Numerical solutions. Journal of Geophysical Research: Oceans 101 (C6):13993-14010.

McCreary, J. P., P. K. Kundu, and R. L. Molinari. 1993. A numerical investigation of dynamics, thermodynamics and mixed-layer processes in the Indian Ocean. Progress in Oceanography 31 (3):181-244.

Muraleedharan, P. M., and S. Prasanna Kumar. 1996. Arabian Sea upwelling a comparison between coastal and open ocean regions. Current Science 71 (11):842-846.

Pankajakshan, T., J. Pattnaik, and A. K. Ghosh. 1997. An atlas of upwelling indices along east and West Coast of India, 55. Goa, India: Indian National Oceanographic Data Center, National Institute of Oceanography.

Potemra, J. T., M. E. Luther, and J. J. O'Brien. 1991. The seasonal circulation of the upper ocean in the Bay of Bengal. Journal of Geophysical Research 96 (C7):12667-12683.

Ramesh, K. V., and R. Krishnan. 2005. Coupling of mixed layer processes and thermocline variations in the Arabian Sea. Journal of Geophysical Research 110:C05005. doi:10.1029/ 2004JC002515.

Rao, A. D., M. Joshi, and M. Ravichandran. 2008. Oceanic upwelling and downwelling in the waters off West Coast of India. Ocean Dynamics 58 (3-4):213-226. doi:10.1007/ s10236-008-0147-4.

Rao, R. R., M. S. Girish Kumar, M. Ravichandran, A. R. Rao, V. V. Gopalakrishna, and P. Thadathil. 2010. Interannual variability of Kelvin wave propagation in the wave guides of the equatorial Indian Ocean, the coastal Bay of Bengal and the southeastern Arabian Sea during 1993-2006. Deep Sea Research I 57 (1):1-13.

Sanilkumar, K. V., V. K. Unni, and V. V. James. 2004. Upwelling characteristics of the southwest coast of India during 2003, Proceedings, METOC-2004.

Schott, F., and J. P. McCreary. 2001. The monsoon circulation of the Indian Ocean. Progress in Oceanography 51 (1):1-123.

Shah, P., R. Sajeev, and N. Gopika. 2015. Study of upwelling along the West Coast of India-A climatological approach. Journal of Coastal Research 31 (5):1151-1158.

Shah, P., R. Sajeev, K. M. Santhosh, K. J. Thara, M. Shafeeque, J. K. Lix, and G. George. 2018. Observed signals of upwelling and downwelling along the West Coast of India. Indian Journal of Geo-Marine Sciences 47 (3):604-612.

Shankar, D., P. N. Vinayachandran, and A. S. Unnikrishnan. 2002. The monsoon currents in the North Indian Ocean. Progress in Oceanography 52 (1):63-120.

Sharma, G. S. 1978. Upwelling of the southwest Coast of India. Indian Journal of Marine Sciences 7:209-218.

Shetye, S. R., and A. D. Gouveia. 1998. Coastal circulation in the North Indian Ocean: Coastal segment (14, S-W). The Sea 11:523-556.

Shetye, S. R., and S. S. C. Shenoi. 1988. Seasonal cycle of surface circulation in the coastal North Indian Ocean. Proceedings of the Indian Academy of Science (Earth and Planetary Science) 97:53-62.

Shetye, S. R., S. S. C. Shenoi, M. K. Antony, and V. Krishna Kumar. 1985. Monthly mean wind stress along the coast of the North Indian Ocean. Proceedings of the Indian Academy of Science (Earth and Planetary Science) 94 (2):129-137.

Sindhu, B., I. Suresh, A. Unnikrishnan, N. Bhatkar, S. Neetu, and G. S. Michael. 2007. Improved Bathymetric Data Set for the Shallow Water Regions in the Indian Ocean. Journal of Earth System Science 116:261-274. doi:10.1007/s12040-007-0025-3. 
Smitha, B. R., V. N. Sanjeevan, K. G. Vimalkumar, and C. Revichandran. 2008. On the upwelling off the Southern tip and along the West Coast of India. Journal of Coastal Research 24 (3):95-102.

Thara, K. J. 2011. Response of eastern Arabian Sea to extreme climatic events with special reference to selected pelagic fishes. Ph.D. thesis, Cochin University of science and Technology, Kochi, India.

Vialard, J., S. S. C. Shenoi, J. P. McCreary, D. Shankar, F. Durand, V. Fernando, and S. R. Shetye. 2009. Intraseasonal response of the Northern Indian Ocean coastal waveguide to the Madden-Julian oscillation. Geophysical Research Letters 36. doi:10.1029/2009GL038450.

Vic, C., X. Capet, G. Roullet, and X. Carton. 2017. Western boundary upwelling dynamics off Oman. Ocean Dynamics 67 (5):585-595.

Vinayachandran, P. N., P. Chauhan, M. Mohan, and S. Nayak. 2004. Biological response of the sea around Sri Lanka to summer monsoon. Geophysical Research Letters 31(1).

Wang, B. 2002. Kelvin waves. Encyclopedia of Atmospheric Sciences 1062-1068.

Yu, L., J. J. O'Brien, and J. Yang. 1991. On the remote forcing of the circulation in the Bay of Bengal. Journal of Geophysical Research 96 (C11):20449-20454. 